
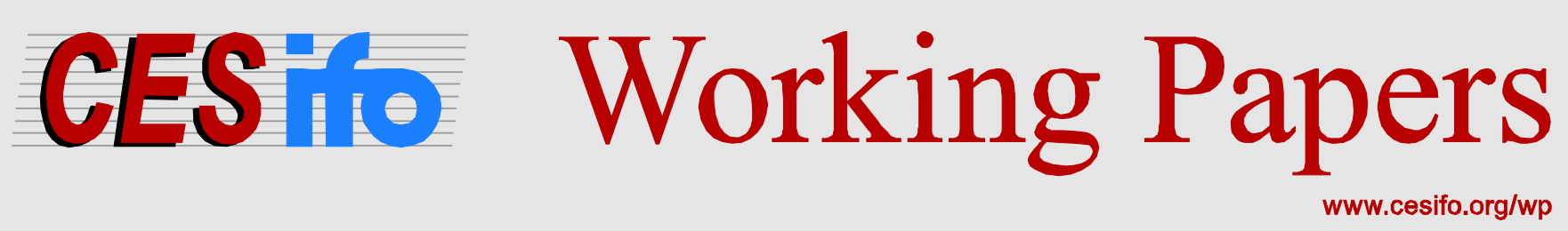

\title{
Service Quality in Electricity Distribution in Brazil: A Malmquist Approach
}

\author{
Alexandre Marinho \\ Marcelo Resende
}

\author{
CESIFO WORKING PAPER NO. 6276 \\ CATEGORY 12: EMPIRICAL AND THEORETICAL METHODS \\ DECEMBER 2016
}

An electronic version of the paper may be downloaded

- from the SSRN website:

- from the RePEc website:

- from the CESifo website:

WwW.SSRN.com

Www.RePEc.org

www.CESifo-group.org/wp

ISSN 2364-1428

\section{CESifo}




\title{
Service Quality in Electricity Distribution in Brazil: A Malmquist Approach
}

\begin{abstract}
The paper undertakes a dynamic analysis for service quality in the electricity distribution in Brazil between 2010 and 2014 based on Malmquist indexes constructed upon Data Envelopment Analysis (DEA) distance functions. The motivation for the less usual consideration of efficiency frontiers for service-quality builds on previous static applications in the context of telecommunications as given by Façanha and Resende (2004), Resende and Façanha (2005) and Resende and Tupper (2009). The analysis treats undesirable technical indicators as inputs and desirable consumer satisfaction indicators as outputs. The bootstrap- corrected Malmquist indexes indicated that service quality is an important concern as the evidence respectively indicates quality deterioration in $38.1 \%$, quality stagnation in $40.5 \%$ and quality improvement only in $21.4 \%$ of the cases. When one decomposes the Malmquist index, the evidence does not suggest relevant frontier shifts and indicates a dominant role for the catch-up effect.
\end{abstract}

Keywords: service quality, consumer satisfaction, electricity distribution, Brazil.

Alexandre Marinho

Instituto de Pesquisa Econômica Aplicada Universidade do Estado do Rio de Janeiro Av. Pres. Antônio Carlos 51/14 $4^{\text {th }}$ Centro Brazil - 20.020-010, Rio de Janeiro-RJ alexandre.marinho@ipea.gov.br
Marcelo Resende Instituto de Economia Universidade Federal do Rio de Janeiro Av. Pasteur 250, Urca Brazil - 22290-240, Rio de Janeiro-RJ mresende@ie.ufrj.br

The authors acknowledge the research assistance from Simone de Souza Cardoso. 


\section{Introduction}

Efficiency assessments of regulated industries have become widespread in applied work and highlight the central role of productive efficiency in the context of regulation. Hence, one can observe that different variants of price cap regulation (PCR) in different regulated sectors in several countries have become prevalent. In fact, there appears to be is a consensus in terms of superior incentives for productive efficiency of PCR relative to traditional rate of return regulation (ROR) regimes [see Liston (1991)].

The electricity distribution sector in Brazil, with its relatively new regulatory settings, has attracted attention in terms of productive efficiency assessments as indicated by Resende (2002), Ramos-Real et al. (2009), Tannuri-Pianto et al. (2009) and Souza et al. (2011). Those studies, either based on stochastic or deterministic efficiency frontiers, highlight the heterogeneity of the sector and the prevalence of non-negligible underperformance in the case of some distribution firms.

However, a possible shortcoming of PCR relates to collateral effects pertaining to service quality degradation. De Fraja and lozzi (2008) theoretically advance the possibility of adjusting the PCR rule for quality, and Currier (2007a, b) discusses some possible adjustment procedures that could be considered in actual regulatory practice. It is worth mentioning that the incorporation of a quality adjustment term (say the $Q$ factor) has given rise to a new debate in different regulatory agencies [see Milne (2003)]. In the case of electricity distribution in Brazil, the regulatory agency recently established rules for the aforementioned adjustments that extended the scope of the tariff rule beyond the usual productivity offset (the so-called $X$ factor). Nevertheless, the debate on how to measure quality and then devise adjustment factors in the PCR rule is by no means settled. Resende and Cardoso (2016) undertook a large-scale study that explored the 
multivariate patterns of different service-quality in indicators in electricity distribution in Brazil and suggested salient quality heterogeneities that, in principle, do not have a clear cut regional pattern and yet indicate quality deterioration between 2010 and 2014 .

However, it is important to further explore the multivariate nature of quality that had been previously acknowledged by Lynch et al. (1994). In fact, a branch of the empirical literature that includes Façanha and Resende (2004), Resende and Façanha (2005) and Resende and Tupper (2009) advanced efficiency frontiers for quality by means of Data Envelopment Analysis (DEA) models for the telecommunications sectors. The adaptation involves interpreting unfavorable quality indicators as inputs and favorable quality indicators as outputs. In the present application for electricity distribution in Brazil, we extend that previous literature by focusing on a dynamic approach in terms of Malmquist indexes that allow the useful decomposition of productivity growth into catchup and frontier shifts. Such an efficiency frontier approach can potentially contribute beyond the more descriptive characterization as the benchmark perspective can eventually provide some relevant guidance for setting the quality adjustment factor under PCR.

The paper is organized as follows. The second section provides basic background on Brazilian electricity distribution and discusses the data sources and variables used in the empirical analysis. The third section makes a brief digression on the Malmquist approach for assessing productivity growth. The fourth presents the empirical results. The fifth section provides some final comments.

\section{Electricity distribution in Brazil}

\section{1- Basic background}


The regulatory institutional framework for electricity distribution in Brazil is relatively new. Following the privatization process in 1995, the regulatory agency Agência Nacional de Energia Elétrica (ANEEL) was created in December 1996, and concerns with efficiency-inducing regulatory regimes gradually became more widespread as PCR was consolidated and the $X$ factors were completely defined by 2003-4. Details on the institutional reforms in the sector are outlined in Mendonça and Dahl (1999), Losekann (2008) and Souza and Legey (2010).

The concern with possible quality degradation under PCR is more recent in the context of the regulatory agency. In fact, it is only in the technical note by ANEEL (2015) that one defines a quality adjustment factor (the $Q$ factor) to be included in the PCR rule together with the usual productivity offset (the $X$ factor). It is noticeable that efficiency measurement methods, for example DEA have attained increasing acceptance at ANEEL; however, the criteria for setting the $X$ and $Q$ factors are non-trivial, and debates on possible improvements are still warranted. In the latter case, in particular, the ranges are defined in accordance with particular values of a consumer satisfaction index. Beyond the choice of adequate quality indicators, it is possible to conceive that DEAbased efficiency frontiers for quality could in principle provide some additional guidance towards the definition of reference firms and therefore further illuminate the setting of the $Q$ factor. ${ }^{1}$

\section{2- $\underline{\text { Data sources }}$}

The present paper constructs Malmquist indexes for quality indicators and takes as a reference distance function based on Data Envelopment Analysis (DEA). More direct technical indicators that we aim to minimize were interpreted as inputs. The indicators for particular distribution firms are averages of sampled consuming units and possess a

\footnotetext{
${ }^{1}$ Resende and Cardoso (2016) provide a descriptive assessment of broad set of service-quality indicators in electricity distribution in Brazil
} 
somewhat aggregate nature. Specifically, we consider five indicators obtained from a specific superintendence [Superintendência de Regulação dos Serviços de Distribuição - SRD] of ANEEL that are available on a quarterly basis:

. Interruption duration by the consuming unit for interruptions greater than or equal to 3 minutes in duration [duração equivalente de interrupção por unidade consumidoraDEC);

. Interruption frequency by the consuming unit for interruptions greater than or equal to 3 minutes in duration [frequência equivalente de interrupção por unidade consumidoraFEC];

- Relative duration of breaching the critical voltage; this indicator indicates the percentage of time during which a precarious voltage prevailed with an established limit of $0.5 \%$ [duração relativa da transgressão de tensão crítica - DRC];

. Relative duration of breaching the precarious voltage; this indicator indicates the percentage of time during which a precarious voltage prevailed with an established limit of 3\% [duração relativa da transgressão de tensão precária - DRP];

. Index for consumer units with critical voltage; this indicator indicates the percentage of consuming units with non-zero DRC relative to the total number of consuming units [índice de unidade consumidora com tensão crítica - ICC].

The outputs considered in the present application are service-quality indicators that one would intend to maximize and that reflect consumer satisfaction. Those are given by a consumer satisfaction index [Índice ANEEL de Satisfação do ConsumidorIASC] that is based on an annual survey of a sample of consumers served by the various distribution firms in Brazil. The indicator is available from a specific superintendence at ANEEL [Superintendência de Mediação Administrativa, Ouvidoria 
Setorial e Participação Pública-SMA]. The overall index is composed of subcomponents in terms of 5 categories: ${ }^{2}$

- perceived quality (PQUAL): considers questions regarding 17 aspects related to information provided to clients, attendance quality and service reliability;

- perceived value (PVAL): reflects benefit relation; considers 3 questions pertaining to the benefits of energy provision, service quality and quality of customer service;

. satisfaction (SAT): considers 3 questions related to global satisfaction, distance to the ideal firm and global nonconformity;

. confidence in the provider (CONF): considers 4 variables to assess the extent to which the firm is trustworthy;

. fidelity (FID): considers 3 variables to assess the potential willingness of the consumer to switch between energy providers. Based on ordinal scales and evaluations of customers of a particular distribution firm, the indexes are weighted measures that emphasize the distances between the best and worst evaluations by the pool of sampled consumers.

Thus, we have technical indicators that are available on a quarterly basis and consumer satisfaction indicators that are obtainable on an annual basis. ${ }^{3}$ The analysis makes use of annual averages when necessary and focuses on the comparison between 2010 and $2014^{4}$

The relevant summary statistics for the aforementioned indicators are presented in Table 1. The list of the 42 firms included in the sample is included in the appendix.

\section{INSERT TABLE 1 AROUND HERE}

\footnotetext{
${ }^{2}$ The indicators described in this sub-section were considered in Resende and Cardoso (2016), where a canonical correlation analysis was undertaken. The present data description relies on that work.

${ }^{3}$ lacobucci et al. (1995) contend that there are conceptual differences between service quality and consumer satisfaction.

${ }^{4}$ The IASC survey was not conducted in 2011 and we intended to consider a reasonable time interval
} 


\section{Malmquist indexes: a brief digression}

\section{1- Introduction}

The input-based Farrell efficiency, or the input efficiency of a production plan $(x ; y)$ relative to a technology $T$, is defined as $E=\min \{E>0 \mid(E x, y) \in T\}$, i.e., it is the maximal proportional contraction of all inputs $x$ that allows us to produce output $y$. Thus, if $E=0.5$, it indicates that we could have saved $50 \%$ off all inputs and still produced the same outputs. Similarly, output-based Farrell efficiency or output efficiency is defined as $\mathrm{F}=\max$ $\{E>0 \mid(x, F y) \in T\}$ and is defined as the maximal proportional expansion of all outputs $y$ that is feasible with the given inputs $\mathrm{x}$. For instance, if $\mathrm{F}=1.5$ one could expand the output vector by $50 \%$ without employing more inputs. In the Farrell approach to the efficiency measurement, all inputs are reduced or alternatively all outputs are expanded by the same factor. This proportional adjustment has been challenged by a series of alternative efficiency measurement approaches. We consider simultaneous improvements on the input and output side by basically combining the Farrell input and output efficiency measures into one measure, sometimes referred to as the graph hyperbolic measure of technical efficiency as $\mathrm{H}=\min \left\{\mathrm{H}>0 \mid\left(\mathrm{Hx}, \frac{\mathrm{y}}{\mathrm{H}}\right) \in \mathrm{T}\right\}$ [Bogetoft and Otto (2011)].

The $\mathrm{H}$ measure tries to simultaneously reduce the inputs and to expand the outputs as in the Farrell approach. The input side is exactly as in the E measure, and the output side is in equal to the $F$ measure. In fact, when we reduce $H$, the reciprocal $1 / H$ is expanded, which is similar to the $\mathrm{F}$ factor in the Farrell output efficiency measures. Also note that for $(x, y) \in T$, we have $H \leq 1$. The interpretation of a hyperbolic efficiency $H$ is that we can reduce input to $\mathrm{Hx}$ and simultaneously expand output to $\frac{1}{\mathrm{H}} \mathrm{y}$.

\section{2- The Malmquist Index}


The most popular approach to dynamic efficiency evaluations is the Malmquist index [see Färe et al. (2008) for a comprehensive overview]. It works without prices to aggregate the different inputs and outputs. The Malmquist measure and its decomposition are useful in capturing dynamic developments from one period to another. To explain the idea of the Malmquist index, let $E(s, t)$ be a measure of the performance of a firm in period s against the technology in -period t. It might, for example, be Farrell input efficiency, i.e., $\left.E(s, t)=\min \left\{E>0 / E x^{s}, y^{s}\right) \in T\right\}$.

Note that we distinguish the technology and the production data depending on the period from which they stem. To measure the improvement in firm $\mathrm{i}$ from period $\mathrm{s}$ to period $t$, we can look at the changes in efficiency compared to a fixed technology. If we use time s technology as the fixed technology, we can use

$$
M^{S}=\frac{E(t, s)}{E(s, s)} .
$$

If the firm has improved from period $s$ to $t$ we will obtain $E(t ; s)>E(s ; s)$, and therefore, $M^{s}>1$. If, on the other hand, the firm is less efficient in period $t$ than period $s$ we will have $E(t, s)<E(s, s)$ and $M^{s}<1 . M^{s}$ measures the improvement relative to technology $s$. We might alternatively have used technology at time $t$ as the fixed technology, in which case we would then obtain

$$
M^{t}=\frac{E(t, t)}{E(s, t)}
$$

Because there is no reason to prefer one to the other, the Malmquist index is simply the geometric mean of the two:

$$
M(s, t)=\left(\frac{E(t, s) E(t, t)}{E(s, s) E(s, t)}\right)^{0.5}
$$

If the firm has improved its performance from period $s$ to period $t$, then we will observe $M(s, t)>1$. If, on the contrary, the firm is less efficient in period $t$ than in period $s$ we will have $\mathrm{M}(\mathrm{s}, \mathrm{t})<1$. 
We can decompose the Malmquist Index into two components [see Färe et al. (1994)]:

$$
M(s, t)=\left(\frac{E(t, t)}{E(s, s)}\right)\left(\frac{E(t, s) E(s, s)}{E(t, t) E(s, t)}\right)^{0.5}=\mathrm{EC}(\mathrm{s}, \mathrm{t}) \cdot \mathrm{TC}(\mathrm{s}, \mathrm{t})
$$

where $\mathrm{EC}(\mathrm{s}, \mathrm{t})=\frac{E(t, t)}{E(s, s)}$ and $\mathrm{TC}(\mathrm{s}, \mathrm{t})=\left(\frac{E(t, s) E(s, s)}{E(t, t) E(s, t)}\right){ }^{0.5}$.

The first component in the decomposition is the efficiency change index EC, which measures the catch-up relative to the current technology. We always measure this factor against the present technology, asking if the firm has moved closer to the frontier. If the answer is positive, $\mathrm{E}(\mathrm{t}, \mathrm{t})>\mathrm{E}(\mathrm{s}, \mathrm{s})$ and $\mathrm{EC}>1$, otherwise we will have $\mathrm{E}(\mathrm{t}, \mathrm{t})<\mathrm{E}(\mathrm{s}, \mathrm{s})$ and $\mathrm{EC}<1$.

The technical change index TC is the geometric mean of two ratios. In both ratios, we fix the firm's production plan at time $t$ and use this as the benchmark against which we measure changes in the technology. If the technology has progressed, we will have $E(t, s)>E(t, t)$ and the first ratio in the geometric mean will be greater than unity. The idea of the second ratio is the same, but here we only use the time s version of our firm as the benchmark when we investigate technological improvements. In short, the TC measures technological change, and TC $>1$ represents technological progress in the sense that more outputs can be produced using fewer inputs.

Similar to the path followed by the DEA literature, the Malmquist-DEA approach has converged towards the consideration of bootstrap resampling methods to ascertain the robustness of the indicators and avoid a purely deterministic formulation. In fact, Simar and Wilson (1999) have advanced a bootstrap algorithm in the context of Malmquist indexes. Once efficiency scores and productivity indexes are obtained and external factors are accounted for, we must still obtain the appropriate confidence intervals for the derived scores and determine whether the obtained scores and indexes are significant. It is well known that DEA results are sensitive to sample composition. 


\section{3 - Application of the Bootstrap in Data Envelopment Analysis}

The bootstrap technique, a variation of the Monte Carlo method developed by Efron (1979), is a computational statistical method used to calculate the accuracy of statistical estimators. It performs simulations, repeatedly, of the Data Generator Process (DGP) through resamplings of the same size with replacement. Replacement means that each new sample created via the bootstrap may have some original observations more than once, while other original observations may not be selected because they are chosen randomly. The goal of this technique is to generate a new random set of data in each resampling and to use the statistic of interest in each of these resamplings to approximate the sampling distribution of the parameter to be estimated and then estimate statistics of interest based on the original sample.

Data Envelopment Analysis addresses neither the randomness nor the measurement error. All deviations from the DMU frontier are assigned as inefficiencies. However, we know that this may not be true as the data may contain measurement errors. In addition, production and consumption activities are subject to various types of shocks and randomness caused by various phenomena beyond the control of DMUs (e.g., weather, quality of certain inputs, strikes, and market-related problems). An important point is that DEA estimators are naturally positively biased because the relative efficiency frontier is estimated based on one sample. Moreover, there is no guarantee that the benchmarks (efficient DMUs) have made their best effort. In that case, the estimated frontier is below the "real" frontier, which is not observed. In the best scenario, the estimated frontier coincides with the "real" frontier. Thus, each DMU is closer to the estimated frontier than the "real" frontier, and DEA estimators are benevolent or biased upward (in favor of DMUs) and overestimated. Because the actual 
frontier is not observed, the additional problem arises that the actual probability distribution of DEA estimators is not known.

The bootstrap technique can mitigate the sensitivity of the DEA in relation to such measurement errors, randomness and bias. The bootstrap can calculate the variance of scores even in an unknown distribution [see Simar and Wilson (1998)]. Thus, it is possible to obtain confidence intervals for the estimated efficiency of each DMU. Simar and Wilson (1999) have demonstrated that the bootstrap technique can also be employed to estimate confidence intervals for Malmquist indexes. The process can be summarized as follows:

1. Compute the Malmquist productivity index $M_{i}^{S}=\frac{E(p, q)}{E(p, q)}$ for each DMU $i=1, \ldots, L$, by solving the following four linear programming models:

$$
\begin{gathered}
\operatorname{Max}_{h, \lambda} h \\
\text { subject to } \\
h y_{0, q} \leq Y_{p} \lambda \\
x_{0, q} \geq X_{p} \lambda \\
\lambda_{i} \geq 0 \\
\text { for }(p, q) \in\{(s, s),(t, t),(s, t),(t, s)\}
\end{gathered}
$$

2. Compute a pseudo data set $\left\{\left(x^{*}{ }_{i s}, y^{*}{ }_{i s}\right) ;\left(x^{*}{ }_{i t}, y^{*}{ }_{i t}\right) i=1, \ldots, L\right\}$ to form the reference bootstrap technology using bivariate kernel density estimation and the adaptation of the reflection method proposed by Simar and Wilson (1999). 
3. Compute the bootstrap estimate of the Malmquist index for each DMU $\widehat{M}_{i b}^{*}(s, t)$ by applying the original estimators to the pseudo sample obtained in step 2 .

4. Repeat steps 2-3 a large number of $B$ times in order to provide a set of estimates $\left\{\widehat{M}_{i 1}^{*}(s, t) \ldots \ldots \widehat{M}_{i b}^{*}(s, t)\right\}$.

5. Compute the confidence interval by using those estimates.

Our objective is to use the distribution of $\left\{\widehat{M}_{l}^{*}(s, t)-\widehat{M}_{l}(s, t)\right\}$ to estimate the unknown distribution of $\left\{\widehat{M}_{i}(s, t)-M_{i}(s, t)\right\}$, where $M_{i}(s, t)$ is the true and unknown Malmquist Index, $\widehat{M}_{\mathrm{i}}(s, t)$ is the original estimate of the Malmquist Index and $\widehat{M}_{\imath}^{*}(s, t)$ is the Malmquist estimate generated by steps 1-4.

Working in a similar manner as before, these bootstrap estimates can be used to perform statistical inference on the productivity indexes through the development of confidence intervals. Therefore, let $b_{\alpha}$ e $a_{\alpha}$ define the unknown confidence interval (1- $\left.\alpha\right)$ such that $\operatorname{Pr}\left(b_{\alpha} \leq \widehat{M}_{\imath}(s, t)-M_{i}(s, t) \leq a_{\alpha}\right)=1-\alpha$.

However, we can use the bootstrap values to determine the values $a^{*}{ }_{\alpha}$ e $b^{*}{ }_{\alpha}$ as follows:

$$
\operatorname{Pr}\left(b^{*} \leq \widehat{M}_{l}^{*}(s, t)-\widehat{M}_{l}(s, t) \leq a^{*}{ }_{\alpha}\right)=1-\alpha
$$

Accordingly, in the spirit of Simar and Wilson (1999), we can find an estimated (1- $\alpha)$ percent confidence interval for the real Malmquist Index such that

$$
\widehat{M}_{l}(s, t)+a_{\alpha}^{*} \leq M_{i}(s, t) \leq \widehat{M}_{l}(s, t)+b^{*}{ }_{\alpha} .
$$

With the information provided above, it is possible to ascertain whether productivity growth (or decline) measured by the Malmquist productivity index is significant, i.e., it is greater than (or less than) unity at the desired significance levels. The same holds for the sources of productivity, as it is now possible to assess the significance of both 
efficiency change and technical change, if they occur. The interpretation is straightforward. In the $95 \%$ confidence interval case, if it contains unity, then the corresponding measure is not significantly different from one at the $5 \%$ significance level, i.e., it is not possible to conclude that changes occurred in efficiency, technology, or productivity. In contrast, when the interval excludes unity, one can conclude with $95 \%$ confidence that the corresponding measure is significantly different from unity. Consequently, as stated by Simar and Wilson (1999), one should be careful when making performance comparisons based on original efficiency scores. While some DMUs might appear to differ when considering only their original and bias-corrected scores, their confidence intervals may overlap. Therefore, in such cases there is no empirical evidence to reject the hypothesis that two such units are equally efficient.

\section{Empirical results}

The results for the bias-corrected Malmquist indexes and corresponding confidence intervals are presented in table 2 . The empirical analysis was implemented with the software library FEAR 2.0 in R language developed by Paul W. Wilson and initially described in Wilson (2008).

\section{INSERT TABLE 2 AROUND HERE}

Table 2 above shows that in 17 out of 42 firms, the $95 \%$ confidence interval contains unity. Consequently, the Malmquist Index is not significantly different from one at the $5 \%$ significance level, and it is not possible to conclude that changes occurred in productivity. As a consequence, there is not enough empirical evidence to reject the hypothesis that such firms have changed their productivity. Generally, we also cannot say that the mean 
and median productivity have changed. By inspecting the confidence intervals we can observe that the productivity has decreased in 16 firms and increased in 9 firms.

The results also show that there are substantial dissimilarities between firms' confidence intervals. Some of estimated confidence intervals are quite wide (e.g., CAIUA, CFLO, CPFLMococa) while others are rather narrow (e.g., ELETROPAULO, ESCELSA).

Moreover, Table 2 additionally shows that LIGHT is only an apparent benchmark in the sample because its confidence interval lower bound is below the upper bounds of CAIUA, CEA, and CHESP. Therefore, LIGHTS's 95\% confidence interval overlaps with those firms' intervals and we cannot ascertain that LIGHT is a true benchmark. The firm that seemingly performs poorly is CEMAR, but its confidence interval overlaps with EBO's interval and we cannot afford to assign it alone as the worst performer in the sample.

If we consider a regional perspective, it is possible to identify quality improvements, mostly in firms operating in the Southeast region and to a smaller extent in the South region, which is one of the most developed regions in Brazil. In the other extreme, quality deterioration appears to be somewhat more prevalent in the Northeast region, although such cases also occur in the Southeast region. In the majority of the cases (17 out of 42), the evidence suggests unchanged quality over the investigated period. Thus, despite the relatively short time interval of the analysis, the evidence seems to suggest that the energy distribution sector is somewhat uneven across the country. Moreover, the Malmquist DEAbased approach allows us to consider multiple dimensions of quality from a dynamic comparative perspective and reinforces the initial descriptive mapping of the sector advanced by Resende and Cardoso (2016), who had highlighted the significant heterogeneity and non-negligible quality under performance. 
The next logical step comprises the usual split of the overall Malmquist index into the catch-up effect (EC) and frontier shift effect (TC). This exploratory assessment is made possible by considering the results displayed in Table 3.

\section{INSERT TABLE 3 AROUND HERE}

It is not surprising that, given the short time interval under consideration, nearly all components associated with frontier shift are close to unity and the change in quality is largely associated with the catch-up component. The magnitudes of such components, which capture changes relative to a given frontier, are especially salient in the extreme cases either for bad or for good as exemplified by CEMAR and LIGHT, respectively. These results, of course, do not necessarily challenge the (static) high quality perceived by the regulatory agency ANEEL, which has praised SULGIPE and RGE in recent years. Nevertheless, it is interesting to observe that when one considers a more comprehensive multidimensional analysis, a firm that was associated with multiple explosions of utilities holes (LIGHT) showed a large relative improvement between 2010 and 2014 .

\section{Final comments}

The paper aimed to provide a dynamic analysis on the evolution of service quality in electricity distribution in Brazil between 2010 and 2014. A key aspect to be considered addresses the multidimensional character of service quality. In fact, the usual focus of regulators on specific indicators can be potentially misleading, and despite the recent introduction of a quality adjustment factor in the price cap rule (the $Q$ factor) in terms of selected indicators, the issue of how to measure quality is by no means settled. The recently introduced rules that establish awards or penalties based on the aggregate consumer satisfaction index IASC in terms of specific discretionary quality thresholds could potentially be improved. In fact, the adoption of a multidimensional perspective that 
considers both direct technical and disaggregated consumer satisfaction indicators might delineate a distinct evaluation of service-quality in electricity distribution that would prevail with the current practice of relying on a smaller set of indicators.

The use of efficiency frontier methods and a benchmarking perspective is already considered in the context of Brazilian regulatory agency ANEEL to indirectly guide the choice of the productivity offset (the $\mathrm{X}$ factor). The present paper suggests that a similar efficiency frontier for service quality may provide some, at least indirect, guidance for setting the quality adjustment factor (the $Q$ factor). The topic warrants additional research, and possible avenues for future research include

a) Improving efficiency frontiers for quality, both by improving the data quality with a longer sample as it becomes available and considering other models and decomposition schemes;

b) Integrating quality into efficiency frontiers for usual inputs and outputs in electricity distribution, for example as overviewed by Yang and Pollitt (2009), who addressed the incorporation of undesirable outputs and uncontrollable variables in DEA models;

c) Considering exogenous determinants of productivity that might affect firms' performance in the spirit of Simar and Wilson (2007), who regressed estimates of efficiency on some covariates in a second stage. 


\section{Appendix}

List of Firms in the Sample [states in which the firm operates are indicated in brackets]

AES Sul Distribuidora Gaúcha de Energia S.A (AES-SUL) [Rio Grande do Sul]

Ampla Energia e Serviços S.A. (AMPLA) [Rio de Janeiro]

Bandeirante Energia S.A. (BANDEIRANTE) [São Paulo]

CAIUÁ - Distribuição de Energia S.A (CAIUÁ) [São Paulo]

Centrais Elétricas de Carazinho S.A. (ELETROCAR) [Rio Grande do Sul]

Centrais Elétricas do Pará S.A. (CELPA) [Pará]

Companhia Campolarguense de Energia (COCEL) [Paraná]

Companhia de Eletricidade do Estado da Bahia (COELBA) [Bahia]

Companhia Energética do Amapá (CEA) [Amapá]

Companhia Energética do Ceará (COELCE) [Ceará]

Companhia Energética do Maranhão (CEMAR) [Maranhão]

Companhia Energética de Pernambuco (CELPE) [Pernambuco]

Companhia Energética do Rio Grande do Norte (COSERN) [Rio Grande do Norte]

Companhia Força e Luz do Oeste (CFLO) [Paraná]

Companhia Hidroelétrica São Patrocínio (CHESP) [Goiás]

Companhia Jaguari de Energia Elétrica (CPFL Jaguari) [São Paulo]

Companhia Leste Paulista de Energia (CPFL Leste Paulista) [São Paulo]

Companhia Luz e Força de Mococa (CPFL Mococa) [Minas Gerais and São Paulo]

Companhia Luz e Força Santa Cruz (CPFL Santa Cruz) [Paraná and São Paulo] 
Companhia Nacional de Energia Elétrica (CNEE) [São Paulo]

Companhia Sul Paulista de Energia Elétrica (CPFL Sul Paulista) [São Paulo]

Companhia Sul Sergipana de Eletricidade (SULGIPE) [Bahia and Sergipe]

Departamento Municipal de Energia de ljuí (DEMEI) [Rio Grande do Sul]

Empresa de Distribuição de Energia Vale Paranapanema S.A. (EDVP) [São Paulo]

Empresa Elétrica Bragantina (EEB) [São Paulo]

ELEKTRO Eletricidade e Serviços S.A. (ELEKTRO) [São Paulo]

Empresa Força e Luz João Cesa Ltda. (EFLJC) [Santa Catarina]

Empresa Luz e Força Santa Maria (ELFSM) [Espírito Santo]

Energisa Borborema Distribuidora de Energia S.A. (EBO) [Paraíba]

Energisa Minas Gerais Distribuidora de Energia S.A. (EMG) [Minas Gerais]

Energisa Nova Friburgo Distribuidora de Energia S.A.. (ENF) [Rio de Janeiro]

Energisa Paraíba Distribuidora de Energia S.A. (EPB) [Paraíba]

Energisa Sergipe Distribuidora de Energia S.A. (ESE) [Sergipe]

Espírito Santo Centrais Elétricas S. A. (ESCELSA) [Espírito Santo]

Força e Luz Coronel Vivida Ltda. (FORCEL) [Paraná]

Força e Luz de Urussanga Ltda. (EFLUL) [Santa Catarina]

Hidroelétrica Panambi S.A. - HIDROPAN [Rio Grande do Sul]

Iguaçu Distribuidora de Energia Elétrica Ltda (IENERGIA) [Santa Catarina]

Light Serviços de Eletricidade S.A. (LIGHT) [Rio de Janeiro]

Metropolitana Eletricidade de São Paulo S.A. (AES ELETROPAULO) [São Paulo]

Nova Palma Energia Ltda. (UHENPAL) [Rio Grande do Sul]

Rio Grande Energia (RGE) [Rio Grande do Sul] 


\section{References}

ANEEL (2015), Metodologia do cálculo do fator X, Nota Técnica no 67/2015SRM/SGT/SRD/ANEEL

Bogetoft, P., Otto, L. (2011), Benchmarking with DEA, SFA, and R, New York: Springer Currier, K.M. (2007a), A practical approach to quality-adjusted price cap regulation, Telecommunications Policy, 31, 493-501

Currier, K.M. (2007b), Quality corrected price cap, Bulletin of Economic Research, 59, 255268

De Fraja, G., lozzi, A. (2008), The quest for quality: a quality adjusted dynamic regulatory mechanism, Journal of Economics \& Management Strategy, 17, 1011-1040

Efron, B., (1979), Bootstrap methods: another look at the jackknife, Annals of Statistics, 7, $1-26$.

Façanha, L.O., Resende, M. (2004), Price cap regulation, incentives and quality: the case of Brazilian telecommunications, International Journal of Production Economics, 92, $133-44$

Färe, R., Grosskopf, S., Lindgren, B., Roos, P. (1994a), Productivity developments in Swedish hospitals: a Malmquist output index approach, In A. Charnes, W.W. Cooper, A. Lewin, L. Seiford (eds.), Data Envelopment Analysis: Theory, Methodology and Applications, Norwell-MA: Kluwer Academic Publishers, 253-272.

Färe, R., Grosskopf, S., Margaritis, D. (2008), Efficiency and productivity: Malmquist and more, In Fried, H.O., Knox Lovell, A., Schmidt, S.S. (eds.), The Measurement of Productive Efficiency and Productivity Growth, New York: Oxford University Press, 522621 
Färe, R., Grosskopf, S., Norris, M., Zhang, Z. (1994), Productivity growth, technical, progress and efficiency change in industrialized countries, American Economic Review, 84, 66-83

lacobucci, D.,, Ostrom, A.L., Grayson, K., A (1995), Distinguishing service quality and customer satisfaction: the voice of the consumer, Journal of Consumer Psychology, 4, 277-303

Lynch, J.G, Buzas, T.E., Berg, S.V. (1994), Regulatory measurement and evaluation of telephone service quality, Management Science, 40, 169-194.

Liston, C. (1993), Price-cap versus rate-of-return regulation, Journal of Regulatory Economics, 5, 25-48

Losekann, L. D. (2008), The second reform of the Brazilian electricity system, International Journal of Global Energy Issues, 29, 75-87

Mendonça, A.F., Dahl, C. (1999), The Brazilian electrical system reform, Energy Policy, 27, $73-83$

Milne, C. (2003). Regulating quality of service. Learning Initiatives on Reforms for Network Economies, /www.lirne.net/2003/resources/tr/chapter 14.pdf

Ramos-Real, F.J., Tovar, B., lootty, M., Almeida, E.F., Pinto, H.Q. (2009), The evolution and main determinants of productivity in Brazilian electricity distribution 1998-2005: an empirical analysis, Energy Economics, 31, 298-305

Resende, M. (2002), Efficiency measurement and prospects for yardstick competition in Brazilian electricity distribution, Energy Policy, 30, 637-647

Resende, M., Cardoso, V. (2016), Mapping service quality in electricity distribution in Brazil: an exploratory study, Texto para Discussão 19/2016, IE-UFRJ, 
Resende, M., Façanha, L.O. (2005), Price cap regulation and service-quality in telecommunications: an empirical study, Information Economics and Policy, 17, 1-12

Resende, M., Tupper, H.C. (2009), Service-quality in Brazilian mobile telephony: an efficiency frontier analysis, Applied Economics, 41, 2299-2307

Simar, L., Wilson, P.W. (1998), Sensitivity of efficiency scores, how to bootstrap in non-

Simar, L., Wilson, P.W. (1999). Estimating and bootstrapping Malmquist indices, European Journal of Operational Research, 115, 459-471.

Simar, L., Wilson, P.W. (2007), Estimation and inference in two-stage, semi-parametric models of production processes. Journal of Econometrics, 136 31-64.

Souza, F.C., Legey, L.F.L. (2010), Dynamics of risk management tools and auctions in the second phase of the Brazilian Electricity Market reform, Energy Policy, 38, 17151733

Souza, M.V.P., Souza, R. C. , Pessanha, Moreira, J.F. (2011), Custos operacionais eficientes das distribuidoras de energia elétrica: um estudo comparativo dos modelos DEA e SFA. Gestão \& Produção, 17, 653-667

Tannuri-Pianto, M.E., Sousa, M.C.S., Arcoverde, F.D. (2009), Fronteiras de eficiência estocásticas para as empresas de distribuição de energia elétrica no Brasil: uma análise de dados de painel, Estudos Econômicos, 39, 221-247

Wilson, P.W. (2008), FEAR 1.0: a software package for frontier efficiency analysis with $\mathrm{R}$, Socio-Economic Planning Sciences, 42, 247-254 
Yang, H., Pollitt, M. (2009), Incorporating both undesirable outputs and uncontrollable variable into DEA: the performance of Chinese coal-fired power plants, European Journal of Operational Research, 197, 1095-1105 
Table 1

Service-quality indicators - summary statistics

\begin{tabular}{|l|l|l|l|l|l|l|l|l|}
\hline Variables & \multicolumn{2}{|c|}{ Mean } & \multicolumn{2}{c|}{ Std. dev. } & \multicolumn{2}{c|}{ Minimum } & \multicolumn{2}{c|}{ Maximum } \\
\hline & 2010 & 2014 & 2010 & 2014 & 2010 & 2014 & 2010 & 2014 \\
\hline inputs & & & & & & & & \\
\hline DEC & 1.641 & 1.356 & 1.628 & 1.007 & 0.010 & 0.020 & 7.931 & 5.284 \\
\hline FEC & 1.233 & 1.045 & 1.133 & 0.966 & 0.010 & 0.130 & 6.050 & 4.891 \\
\hline DRC & 0.443 & 0.496 & 0.944 & 0.923 & 0.000 & 0.000 & 4.007 & 3.728 \\
\hline DRP & 1.701 & 1.845 & 3.056 & 2.740 & 0.012 & 0.060 & 15.765 & 14.115 \\
\hline ICC & 7.919 & 6.755 & 8.022 & 6.250 & 0.417 & 0.417 & 30.159 & 33.189 \\
\hline outputs & & & & & & & & \\
\hline CONF & 64.832 & 66.313 & 8.589 & 9.461 & 40.920 & 45.860 & 77.970 & 84.400 \\
\hline FID & 45.219 & 38.063 & 8.907 & 9.169 & 22.250 & 22.480 & 63.790 & 69.470 \\
\hline PQUAL & 69.703 & 69.279 & 9.235 & 9.637 & 41.350 & 46,680 & 83.340 & 85.250 \\
\hline SAT & 66.665 & 70.605 & 8.132 & 8.573 & 46.250 & 47.490 & 81.480 & 84.740 \\
\hline PVAL & 41.199 & 37.004 & 5.351 & 5.804 & 30.400 & 25.520 & 53.300 & 53.770 \\
\hline
\end{tabular}


Table 2

Malmquist indexes and confidence intervals for quality indicators (2014 vs. 2010)

\begin{tabular}{|c|c|c|c|}
\hline \multirow{2}{*}{ Firms } & \multicolumn{2}{|c|}{ confidence interval } & \multirow{2}{*}{ MALM } \\
\hline & lower bound (2.5\%) & upper bound (97.5\%) & \\
\hline AES-SUL & 0.745 & 0.952 & $0.901^{*}$ \\
\hline AMPLA & 1.431 & 2.074 & $1.770^{\star \star \star *}$ \\
\hline BANDEIRANTE & 0.652 & 1.001 & $0.858^{* \star}$ \\
\hline CAIUA & 1.471 & 2.815 & $2.364^{* \star \star}$ \\
\hline CEA & 2.386 & 2.719 & $2.473^{\star \star \star}$ \\
\hline CELPA & 0.438 & 0.531 & $0.462^{*}$ \\
\hline CELPE & 0.911 & 1.412 & $1.312^{\star \star}$ \\
\hline CEMAR & 0.230 & 0.320 & $0.268^{*}$ \\
\hline CFLO & 0.941 & 1.796 & $1.645^{\star \star}$ \\
\hline CHESP & 1.519 & 2.402 & $1.932^{* * *}$ \\
\hline CNEE & 0.856 & 1.150 & $1.077^{\star \star}$ \\
\hline COCEL & 0.346 & 0.552 & $0.423^{*}$ \\
\hline COELBA & 0.893 & 1.211 & $1.087^{* \star}$ \\
\hline COELCE & 0.601 & 0.701 & $0.648^{*}$ \\
\hline COSERN & 0.679 & 0.900 & $0.800^{*}$ \\
\hline CPFLJaguari & 0.621 & 0.885 & $0.680^{*}$ \\
\hline CPFLLestePaulista & 0.760 & 1.302 & $0.965^{\star *}$ \\
\hline CPFLMococa & 0.653 & 1.350 & $1.081^{* *}$ \\
\hline CPFLSantaCruz & 1.222 & 1.457 & $1.251^{* * *}$ \\
\hline CPFLSulPaulista & 0.880 & 1.129 & $0.969^{* \star}$ \\
\hline DEMEI & 0.727 & 0.914 & $0.850^{*}$ \\
\hline EBO & 0.243 & 0.634 & $0.525^{*}$ \\
\hline EDEVP & 0.991 & 1.309 & $1.162^{\star \star}$ \\
\hline EEB & 0.835 & 1.190 & $1.115^{\star \star}$ \\
\hline
\end{tabular}




\begin{tabular}{|c|c|c|c|}
\hline EFLJC & 0.586 & 0.906 & $0.737^{\star}$ \\
\hline EFLUL & 0.702 & 0.971 & $0.754^{*}$ \\
\hline ELEKTRO & 0.917 & 1.092 & $0.953^{* *}$ \\
\hline ELETROCAR & 0.705 & 0.924 & $0.862^{*}$ \\
\hline ELETROPAULO & 0.482 & 0.539 & $0.519^{*}$ \\
\hline ELFSM & 1.063 & 1.521 & $1.266^{\star \star \star}$ \\
\hline EMG & 0.755 & 0.993 & $0.889^{\star}$ \\
\hline ENF & 0.792 & 1.308 & $1.118^{\star *}$ \\
\hline EPB & 0.824 & 1.046 & $0.956^{\star \star}$ \\
\hline ESCELSA & 0.654 & 0.771 & $0.671^{*}$ \\
\hline ESE & 0.940 & 1.259 & $1.185^{\star \star}$ \\
\hline FORCEL & 0.691 & 1.301 & $1.101^{* *}$ \\
\hline HIDROPAN & 0.673 & 0.846 & $0.778^{*}$ \\
\hline IENERGIA & 1.243 & 1.871 & $1.585^{\star \star \star}$ \\
\hline LIGHT & 2.375 & 3.656 & $2.953^{* * *}$ \\
\hline RGE & 1.040 & 1.323 & $1.109^{\star \star \star}$ \\
\hline SULGIPE & 0.887 & 1.129 & $1.026^{\star *}$ \\
\hline UHENPAL & 0.626 & 1.004 & $0.779^{\star \star}$ \\
\hline \multicolumn{4}{|l|}{ Summary statistics } \\
\hline MEDIAN & 0.776 & 1.129 & 0.967 \\
\hline MEAN & 0.881 & 1.266 & 1.092 \\
\hline STD DEV & 0.439 & 0.650 & 0.543 \\
\hline MINIMUM & 0.230 & 0.320 & 0.268 \\
\hline MAXIMUM & 2.386 & 3.656 & 2.953 \\
\hline
\end{tabular}

Note: $\left({ }^{*}\right)$ quality deterioration; $\left({ }^{* \star}\right)$ unchanged quality; $\left({ }^{* \star *}\right)$ quality improvement 
Table 3

Malmquist indexes and decompositions for quality indicators (2014 vs. 2010)

\begin{tabular}{|c|c|c|c|}
\hline Firms & MALM & EC & TC \\
\hline AES-SUL & 0.901 & 0.761 & 1.185 \\
\hline AMPLA & 1.770 & 1.525 & 1.161 \\
\hline BANDEIRANTE & 0.858 & 0.768 & 1.117 \\
\hline CAIUA & 2.364 & 2.119 & 1.116 \\
\hline CEA & 2.473 & 2.120 & 1.166 \\
\hline CELPA & 0.462 & 0.391 & 1.179 \\
\hline CELPE & 1.312 & 1.170 & 1.122 \\
\hline CEMAR & 0.268 & 0.250 & 1.074 \\
\hline CFLO & 1.645 & 1.496 & 1.100 \\
\hline CHESP & 1.932 & 1.701 & 1.136 \\
\hline CNEE & 1.077 & 0.930 & 1.158 \\
\hline COCEL & 0.423 & 0.477 & 0.886 \\
\hline COELBA & 1.087 & 1.027 & 1.058 \\
\hline COELCE & 0.648 & 0.579 & 1.120 \\
\hline COSERN & 0.800 & 0.723 & 1.106 \\
\hline CPFLJaguari & 0.680 & 0.668 & 1.019 \\
\hline CPFLLestePaulista & 0.965 & 0.997 & 0.968 \\
\hline CPFLMococa & 1.081 & 1.000 & 1.081 \\
\hline CPFLSantaCruz & 1.251 & 1.243 & 1.007 \\
\hline CPFLSuIPaulista & 0.969 & 0.792 & 1.224 \\
\hline DEMEI & 0.850 & 0.995 & 0.854 \\
\hline EBO & 0.525 & 0.500 & 1.049 \\
\hline EDEVP & 1.162 & 0.975 & 1.191 \\
\hline EEB & 1.115 & 0.991 & 1.125 \\
\hline EFLJC & 0.737 & 1.000 & 0.737 \\
\hline EFLUL & 0.754 & 0.725 & 1.040 \\
\hline
\end{tabular}




\begin{tabular}{|l|c|c|c|}
\hline ELEKTRO & 0.953 & 0.900 & 1.058 \\
\hline ELETROCAR & 0.862 & 0.714 & 1.207 \\
\hline ELETROPAULO & 0.519 & 0.477 & 1.087 \\
\hline ELFSM & 1.266 & 1.171 & 1.081 \\
\hline EMG & 0.889 & 0.833 & 1.068 \\
\hline ENF & 1.118 & 1.222 & 0.915 \\
\hline EPB & 0.956 & 0.791 & 1.209 \\
\hline ESCELSA & 0.671 & 0.647 & 1.036 \\
\hline ESE & 1.185 & 1.012 & 1.171 \\
\hline FORCEL & 1.101 & 1.000 & 1.101 \\
\hline HIDROPAN & 0.778 & 0.879 & 0.886 \\
\hline IENERGIA & 1.585 & 1.540 & 1.029 \\
\hline LIGHT & 2.953 & 2.279 & 1.296 \\
\hline RGE & 1.109 & 0.968 & 1.146 \\
\hline SULGIPE & 1.026 & 0.900 & 1.140 \\
\hline UHENPAL & 0.779 & 0.885 & 0.880 \\
\hline Summary statistics & & & \\
\hline MEDIAN & 0.967 & 0.949 & 1.100 \\
\hline MEAN & 0.268 & 0.250 & 0.737 \\
\hline STD DEV & 2.279 & 1.296 \\
\hline MINIMUM & & & \\
\hline MAXIMUM & & & \\
\hline
\end{tabular}

